\title{
Development of $\mathrm{ZnO}$ nanoparticles as an efficient $\mathrm{Zn}$ fertilizer: Using synchrotron-based techniques and laser ablation to examine elemental distribution in wheat grain
}

Hongda Sun, ${ }^{\dagger}$, Wei Du, ${ }^{\dagger}$ Qingqing Peng, ${ }^{\dagger}$ Zhiyuan Lv, ${ }^{\dagger}$ Hui Mao, ${ }^{*}, \dagger,+$ and Peter M. Kopittke

$\dagger$ College of Natural Resources and Environment and $\$$ Key Laboratory of Plant Nutrition and the Agri-environment in Northwest China, Ministry of Agriculture, Northwest A\&F University, Yangling, Shaanxi 712100, People's Republic of China

$\S$ School of Agriculture and Food Sciences, The University of Queensland, St. Lucia, Queensland 4072, Australia

Corresponding Author

*Telephone/Fax: +86-29-8708-0055. E-mail: maohui@nwsuaf.edu.cn.

Contents:

Table S1 Effects of different $\mathrm{Zn}$ treatments on total shoot biomass of winter wheat.

Table S2 Effects of Zn application on enzyme activities in tissues of wheat seedlings 
Table S1 Effects of different Zn treatments on total shoot biomass of winter wheat. The first harvest was in 2017 and the second in 2018.

Total Shoot biomass

\begin{tabular}{ccc} 
Treatment & \multicolumn{2}{c}{$\left(\mathrm{kg} \cdot \mathrm{ha}^{-1}\right)$} \\
\cline { 2 - 3 } & $1^{\text {st }}$ & $2^{\text {nd }}$ \\
\hline Control & $11,300 \mathrm{a}$ & $12,500 \mathrm{a}$ \\
Zn-2 & $11,800 \mathrm{a}$ & $12,300 \mathrm{a}$ \\
$\mathrm{ZnO}-2$ & $10,600 \mathrm{a}$ & $12,700 \mathrm{a}$ \\
$\mathrm{ZnO}-4$ & $11,600 \mathrm{a}$ & $11,800 \mathrm{a}$ \\
\hline
\end{tabular}

Note: Data are the average of the four replicates. Different letters indicate statistical differences between treatments $(\mathrm{P}<0.05)$. 
Table S2 Effects of Zn application on enzyme activities in tissues of wheat seedlings. Data are shown for catalase (CAT) and peroxidase (POD).

\begin{tabular}{ccccc}
\hline Treatment & \multicolumn{2}{c}{ CAT $\left(\mathrm{U} \mathrm{g}^{-1} \mathrm{~min}^{-1}\right)$} & \multicolumn{2}{c}{ POD $\left(\mathrm{U} \mathrm{g}^{-1} \mathrm{~min}^{-1}\right)$} \\
\cline { 2 - 5 }$\left(500 \mathrm{mg} \cdot \mathrm{L}^{-1}\right)$ & Root & Shoot & Root & Shoot \\
\hline Control & $1.7 \mathrm{~b}$ & $12.6 \mathrm{a}$ & $37,500 \mathrm{~b}$ & $6,700 \mathrm{~b}$ \\
$\mathrm{Zn}$ & $0.6 \mathrm{c}$ & $11.8 \mathrm{a}$ & $42,500 \mathrm{~b}$ & $31,100 \mathrm{a}$ \\
$\mathrm{ZnO}$ & $2.6 \mathrm{a}$ & $13.5 \mathrm{a}$ & $80,500 \mathrm{a}$ & $8,900 \mathrm{~b}$ \\
\hline
\end{tabular}

Note: Data are the average of the four replicates. Different letters indicate statistical differences between treatments $(\mathrm{P}<0.05)$. 